\title{
Coğrafi bilgi sistemleri ile Niğde-Kayseri arası hızlı tren hattı önerisi ve maliyet değerlendirilmesi
}

\section{High speed rail route proposing using GIS and evaluation of approximate cost between Niğde-Kayseri}

\author{
Yusuf Kağan Demir 1,*(iD, Murat Çoşkun² \\ ${ }^{l}$ Niğde Ömer Halisdemir Üniversitesi, İnşaat Mühendisliği Bölümü, 51240, Niğde Türkiye \\ ${ }^{2}$ Niğde Ömer Halisdemir Üniversitesi, Fen Bilimleri Enstitüsü, 51240, Niğde Türkiye
}

\begin{abstract}
Özet
Günümüzde yüksek hızlı tren (YHT) sistemleri belirli mesafelerde havayolu ulaşımına rakip olmakla beraber özellikle Avrupa bölgesinde havayolu türünün önemli ve tamamlayıcı parçası olarak işletilmektedir. Bu işletme türü düşük yoğunluklu kentlerin hava ulaşım hizmetine ulaşmasının yanında bağlantı kurduğu kentler arasındaki hareketliliğe de katkıda bulunmaktadır. $\mathrm{Bu}$ çalışma Türkiye'deki düşük yoğunluklu kentler için yerel havalimanı planlamalarının yerine mevcut demiryolu bağlantılarının iyileștirilmesi düşüncesi ile Niğde-Kayseri arasındaki demiryolu hattının YHT hattına dönüştürülmesini ve bunun kaba maliyetini hesaplamayı amaçlamaktadır. Çalışma sonucunda Niğde-Kayseri hızlı tren hattının uzunluğu $127 \mathrm{~km}$, yolculuk süresi 60 dakika, kaba maliyeti 2,629,206,080.6 TL olarak hesaplanmıştır. Yerel bir havayolu inşasına göre hattın maliyeti dört kat yüksek tahmin edilmiştir. Ancak düşük yoğunluklu kentlerin ürettiği yetersiz havalimanı talebi düşünüldüğünde hızlı tren yolu hattının Niğde kentine orta ve uzun vadede sosyal ve ekonomik açıdan daha fazla katkıda bulunulacağı düşünülmektedir.
\end{abstract}

Anahtar kelimeler: Hızlı tren, Güzergah, CBS, Maliyet

\section{Giriş}

Havalimanları sürdürülebilir ve etkili işletme için kentin ve çevre yerleşimlerin yarattığ sosyal ve ekonomik değişkenlere bağlı olan belirli bir düzeyde talebe ihtiyaç duyarlar. Niğde gibi düşük yoğunluklu kentlerde bu talebi yaratabilmek için nüfus yoğunluğu ve ekonomik faaliyetler yeterli olmamaktadır. Örneğin nüfusu Niğde'ye benzer büyüklükte olan Uşak havalimanını yılın en kalabalık ayı olan Ağustos ayında 2018'de günlük ortalama 698 yolcu kullanmıştır [1]. Düşük talep; daha az uçuş sıklıklarına, yüksek bilet fiyatlarına ve uçuş noktası çeşitliliğini azaltarak daha fazla aktarmaya neden olmaktadır. Bu nedenle çoğu zaman kente ait yerel bir havalimanı olmasına rağmen yolcular çevre kentlerde fiyat, aktarma ve sıklık bakımından olanakları daha uygun havalimanlarına yönelebilmektedir.

Çalışmanın temel çıkış amacı, yerel bir havalimanı yerine Niğde'yi Kayseri'ye ve Kayseri Havalimanına bağlayan bir

\begin{abstract}
High-Speed Rail (HSR) systems are being operated in the European region as an important complement part of air transportation systems though it competes with air transportation in certain distances. The integration of railway systems to air transportation not only gives cities mobility but also access to the airport for cities having a lack of an airport. The study aims to research development of the existing railway line between Niğde and Kayseri into an HSR system that may alternate to local airport construction and evaluate the approximate cost of HSR construction. As a result, the length, the average travelling time, and the total construction costs of the proposed HSR line between Niğde-Kayseri are $127 \mathrm{~km}, 60$ minutes and 2.629.206.080,6 TL, respectively. The approximate construction cost of the proposed HSR line is about four times higher than new local airport construction. Considering that airports located in low-density population regions are far away from generating enough demand, the proposed HSR line may contribute to Niğde socially and economically more than a local airport in the middle and long terms.
\end{abstract}

\section{Keywords: High speed train, Route, GIS, Cost}

hızlı tren güzergahının önerilmesiyle kentin erişilebilirlik ve uçuş sıklığı bakımından uygun olan, düşük aktarmalı ve ucuz biletlere erişim kolaylığı sağlayan bir havalimanına hızlı bağlantısının kurulması düşüncesine dayanmaktadır. Avrupa'da birçok büyük havalimanı demiryolu bağlantısına sahiptir. Örneğin Lufthansa havayolları demiryolu bağlantısı olan havalimanlarında Rail\&Fly [2] programı kapsamında uçak ve tren biletlerini beraber satarak yolcuların tren-uçak ya da uçak-tren arası geçişlerini kolaylaştırmaktadır. Niğde için önerilen hızlı tren hattının da benzer bir model uygulanarak 45 60 dakikalık yolculukla doğrudan uçuşa geçebilecek biçimde işletilmesi mümkün görülmektedir.

Niğde ve Kayseri kentlerinin YHT ile birbirine bağlanmasının nedenleri aşağıdaki gibi sıralanabilir:

- Karayolu ulaşım sistemlerine göre daha az gürültülü olması, karayoluna göre daha çevreci olması, yük ve yolcu için birim uzaklık başına düşük kirlilik değerlerine sahip olması,

\footnotetext{
* Sorumlu yazar / Corresponding author, e-posta / e-mail ykdemir@ ohu.edu.tr:(Y.K. Demir)

Geliş / Recieved: 31.03.2021 Kabul / Accepted: 05.05.2021 Yayımlanma / Published: 27.07.2021

doi: 10.28948/ngmuh.907098
} 
- Modern, hızlı, konforlu, güvenli olması ve trafik sıkışıklığından etkilenmemesi,

- Zorlu hava veya iklim koşullarından diğer ulaşım türlerine göre daha az etkilenmesi,

- Kaza riskinin diğer ulaşım sistemlerine göre daha az olmas1,

- Taşıdığ1 yolcu sayısı ve taşıdığı navlun oranı dikkate alındığında diğer sistemlere göre avantajlarının olması,

- Uzun vadede Fayda-Maliyet oranlarının daha yüksek değerlere sahip olması

- Kullandığı elektrik enerjisinin üretiminin temiz ve sürdürülebilir kaynaklardan sağlanma olanağ

- İşletme aralıklarının düzenli olması

- İşletme süresince yüksek istihdama sahip bir ulaştırma türü olmasi.

Bu çalışmada, coğrafi bilgi sistemleri yardımıyla NiğdeKayseri arasında bulunan mevcut demir yolu hattının, hızlı demiryolu hattına çevrilmesi durumunda, yeni hatta ait güzergah çalışması yapmak ve hattın kaba maliyetini hesaplayarak raylı sistem seçeneğine dikkat çekilmek istenmiştir.

Dünyada raylı sistem güzergah araştırması için yeni yöntemler uygulanmaktadır. $\mathrm{Bu}$ yöntemlerden en çok kullanılanı coğrafi bilgi sistemi (CBS) ve uzaktan algilama temelli güzergah çalışmalarıdır. Bu alanda yapılmış birçok çalışma bulunmaktadır. [3-11]

\section{Materyal ve Yöntem}

\subsection{Coğrafi bilgi sistemi ve güzergah tayini için çok} kriterli karar verme

Coğrafi bilgi sistemi (CBS) ulaşım sistemlerinin planlanması, izlenmesi ve yönetilmesinde daha s1k kullanılmaktadır. Sürdürülebilir bir ulaşım kararlarının alınması ve ulaşım sistemlerinin planlanmasında coğrafi bilgi sistemi (CBS) tabanlı çok kriterli karar analizi (ÇKKA) kullanılmaya başlanmıştır.

\subsubsection{Coğrafi bilgi sistemi}

Coğrafi bilgi sistemi, dünya genelindeki karmaşık sosyal, ekonomik ve çevresel sorunları saptama, geniş alanların coğrafi verilerini toplama, depolama, işleme, yönetme, tematik analiz yapma, sorgulama ve sunma işlevlerini yerine getiren bir yazılım, donanım, coğrafi bilgi sistemidir [12]. Yani Coğrafi Bilgi Sistemi, teknolojik yöntemler kullanılarak dünyanın matematiksel haritalamasında kullanılan bilgisayar tabanlı bir sistemdir. Bu sistem, olay ve nesnelerin coğrafi bir ilişki içinde hızlı biçimde belirlenmesini sağladığından stratejik olarak önemlidir.

Uydu teknolojileri ve veri işlemede kat edilen mesafe dikkate alındığında raylı sistem hat güzergahlarının belirlenmesinde yeni bir yaklaşım gün yüzüne çıkmıştır. CBS ve uzaktan algılama (UA) kullanımı dünya çapında yapılan çalışmalarda olumlu sonuçlar vermiştir.

Arazide yapılacak pek çok çalışma, uydu görüntüleri ve hava fotoğrafları sayesinde ofis ortamında yürütülebilmektedir. Toplanan veriler, eldeki diğer verilerle de entegre edilerek CBS platformlarında işlenebilmekte ve bu sayede çok çeşitli analiz ve sorgulama sonuçlarına erişilebilmektedir [13]. Geleneksel yöntemlere bakılarak daha fazla iş gücünden, zamandan ve bütçeden tasarruf sağlamaktadır. Ek olarak sayısal çizimlerle ifade edilemeyecek pek çok sözel detay coğrafi nesnelerle kolayca ilişkilendirilmektedir.

Uzaktan Algılama; "Dünyanın karasal yüzeyinden belirli mesafelerde konumlandırılmış platformlara yerleştirilen ölçüm aletleri ile yeryüzündeki doğal veya doğal olmayan nesneler hakkında bilgi edinme ve değerlendirme teknikleri olarak tanımlanmaktadır" [14]. Uzaktan Algılama teknolojisi başlıca şu alanlarda kullanılmaktadır:

- Baraj alanları ve su yataklarının belirlenmesi,

- Deniz ve kıyı araştırmaları ile kirlilik düzeylerinin ve coğrafi değişikliklerin ölçülmesi,

- Raylı sistem, karayolu, gaz ve petrol boru güzergahı seçimi,

- Arazi ve toprak haritalarının oluşturulması,

- Orman kaynakları için varlık değerlendirilmesi

- Orman yangınları, seller, toprak kaymaları gibi doğal afetlerin araştırılması,

- Minerallerin (madenlerin) araştırılmasında jeolojik araştırmaların gerçekleştirilmesi,

- Yerel yönetimlerin kadastro, imar planları ve arazi uygulamalarının yapılması,

- Kaçak inşaatların belirlenmesi vb.

CBS, basit veri katmanlarını nesne sınıfları olarak yönetir (Şekil 1) ve bu veri katmanlarıyla birçok ilişki elde edebilir.

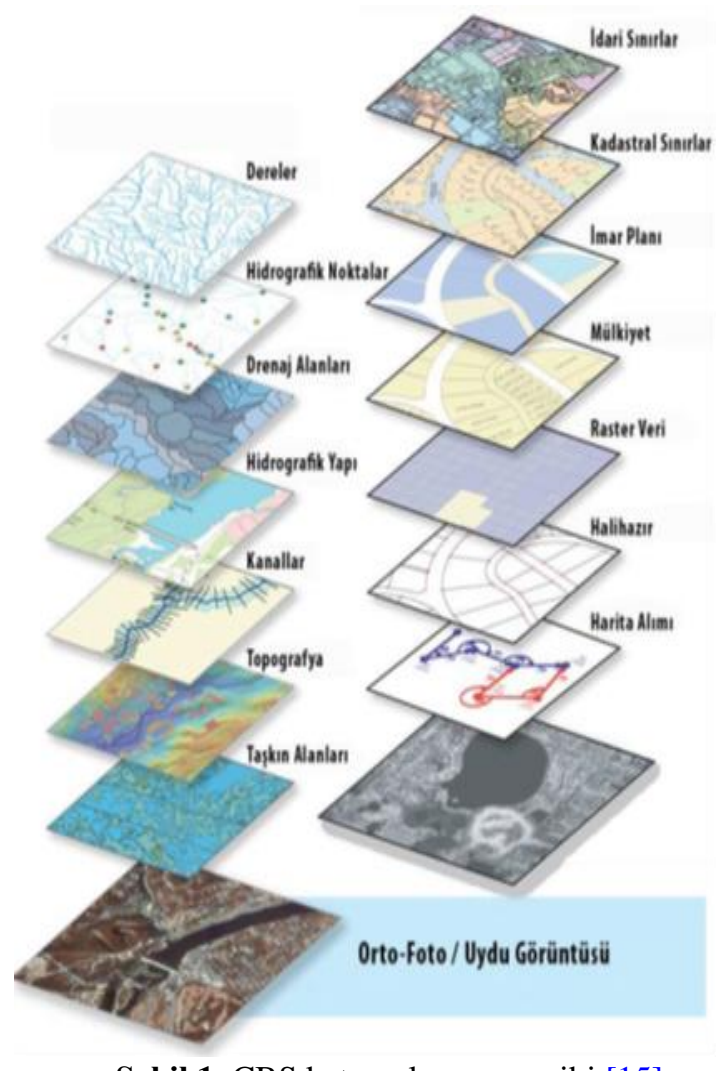

Şekil 1. CBS katmanlama prensibi [15] 


\subsection{Raylı sistem hatlart için güzergah belirleme}

Raylı sistem planlamasının en önemli aşaması güzergah belirlemedir. Ulaşım etüdü yapılarak ihtiyaçlar bölgeye göre belirlenir, daha sonra bu bölgeye hizmet edecek hatta ait güzergah araştırmasına başlanır. Yolculuk talebinin yüksek olduğu alanlar belirlenir ve istasyon yerleri seçilir. İstasyon yerleri belirlendikten sonra güzergah bu istasyonlar arasında araştırmaya başlanır.

Yapılan etütler sonucunda bölgeye uygun ulaşım sistemi belirlenir ve hiç raylı sisteme ihtiyaç duymadan diğer ulaşım sistemleri ile çözülebilir. Eğer kara trafiği veya hava trafiği şartları uygun değilse raylı sistemler tercih edilir. Bölgeye en uygun raylı sisteme karar verildikten sonra güzergah araştırmasına başlanır.

Ulaşım yatırımlarının değerlendirilmesi sürecinde ülkeden ülkeye, hatta ülke içinde bölgeden bölgeye ve uygulayan kişiden kişiye değişen pek çok yöntem uygulanmaktadır. Fakat bunlar içinde yaygın kabul gören iki yöntem 'Çok Kriterli Karar Verme Sistemleri' ve 'Fayda Maliyet Analizi' olarak karşımıza çıkmaktadır. Fayda Maliyet analizi yatırıma tekil bir oransal değerle yaklaşır ve kentsel yap1, siluet, tarihi doku vb. bileșenleri hemen hemen tamamen göz ardı eder. Bu çözümle; maliyet kalemini oluşturan ögeleri ve sonuçta elde edilen faydaları listeleyip toplam maliyet ve faydaların oranlanmasına dayanır. $\mathrm{Bu}$ çözümleme ile maliyet ve faydalara, çevre ve sosyal maliyet ve faydalar dâhil edilerek daha sürdürülebilir yatırımları öne çıkaran çözümlemeler elde etmek mümkündür. Kamu hizmeti taşıyan projelerde maddi olarak ifade edilemeyecek pek çok diğer etken de dikkate alınmalıdır. Bu sebeplerden ötürü, raylı sistem güzergah tasarımı yapılırken konunun bütün açılardan değerlendirilebilmesi amacıyla "Çok Kriterli Karar Verme (ÇKKV) Yöntemlerinden" öne çıkmaktadır. $\mathrm{Bu}$ yöntem "hem sayısal olarak ifade edilebilen hem de edilemeyen değişkenlerin bir arada değerlendirilmesini sağlamaktadır" [4]. Her iki çalışma da uzun ve detayl analizler içerir. Çalışma sadece Niğde-Kayseri arasında önerilen hızlı tren hattının mevcut şartlar altında kaba maliyetini hesaplamaktadır. Ayrıca uygunluk (fizibilite) çalışmaları birden fazla güzergah önerisi içermelidir. Ancak bu çalışmada mevcut hattın hızlı tren hattına çevrilmesi durumundaki maliyet araştırıldığından farklı güzergah önerileri üzerinde çalışılmamıştır.

Raylı sistem türleri hakkındaki karar sürecinde değerlendirilmesi gereken ana ölçütler aşağıda verilmiştir [16].

1. Yolculuk taleplerine göre şekillenen sistem kapasitesi

2. İşletme hızı

3. Topografya

4. Lokomotife bağlı vagon sayısı

5. Yatay kurb büyüklükleri

6. Sinyal sistemi

7. Karayolu ile kesişme oranı

8. İstasyon bölgelerindeki platform uzunlukları

9. İstasyonlar arası mesafe

10. Düşey eğimler

11. Sefer sıklığ 1

\subsubsection{Raylı sistem güzergâh belirlemesine etki eden faktörler}

Raylı sistem hattına ait güzergah çalışması için öncelikle ölçütlerin belirlenmesi ve bu kriterlerin hepsinin bir arada değerlendirilerek en uygun çözümün üretilmesi gerekmektedir.

Şekil 2'de literatür taramalarının ardından Niğde-Kayseri arasındaki raylı sistem hattına güzergah çalışması için 12 faktör göz önüne alınmış ancak bunlardan en çok etkili olanları değerlendirilmiştir.

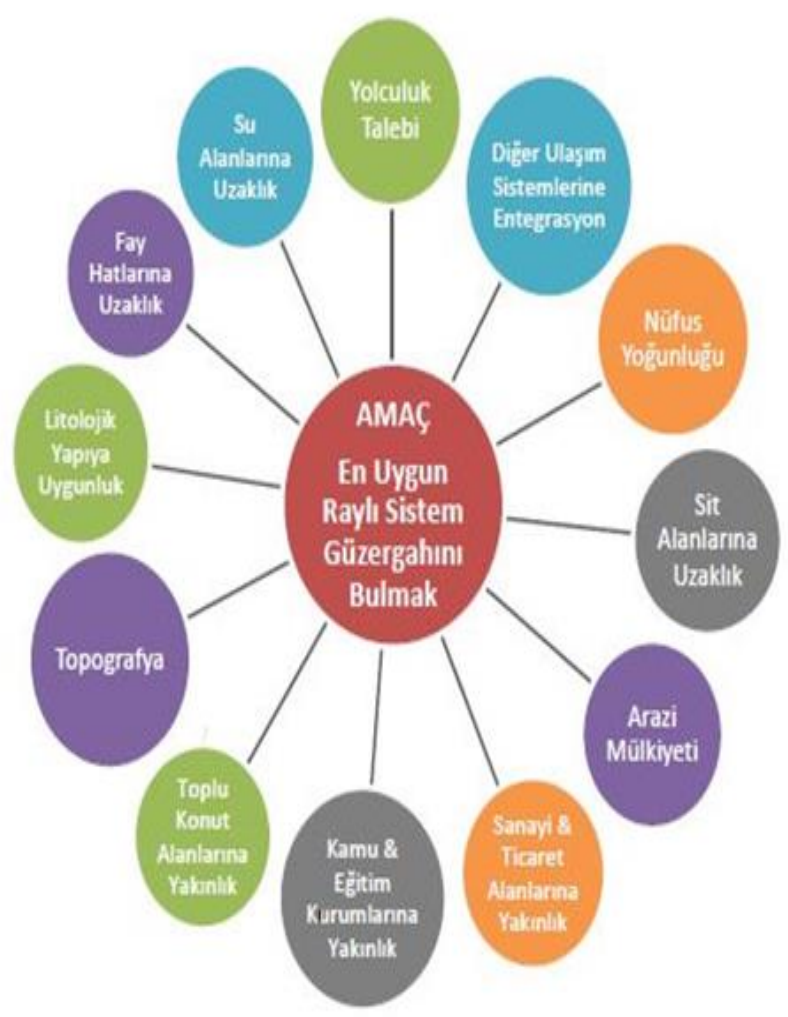

Şekil 2. Raylı sistem güzergah tasarımına etki eden faktörler [4]

\section{Bulgular ve tartışma}

\subsection{Niğde-Kayseri arasında raylı sistem hattı güzergahı}

Raylı sistem çalışmalarının en önemli parçası hatta ait güzergahın belirlenmesidir. Güzergah belirlendikten sonra raylı sistem için fen ve mühendislik çözümlemelerine geçilebilir. Mühendislik çözümünden sonra seçilen güzergahın ekonomik boyutları ele alınabilir.

\subsubsection{Yolcu talebi}

Niğde-Kayseri arasında havalimanına, büyük sağlık merkezlerine, alışveriş ve eğitim alanlarına günlük yoğun bir talepler oluşmaktadır. Niğde ve Kayseri arasında hafta için günlük tek yönde doğrudan 17 otobüs seferi [17] mevcuttur. 2019 verilerine göre yıllık ortalama günlük trafik 1705 otomobil ve 52 otobüs olarak kaydedilmiştir [18]. Otomobil dolulukları 2 kişi/otomobil olarak kabul edildiğinde NiğdeKayseri arasında ortalama yolcu talebi günlük 3410 kişi olarak tahmin edilmektedir. 


\subsubsection{Diğer ulaşım sistemleri ile entegrasyon faktörü}

Aktarma sayılarının düşük olması ve erişimin kolay olması için sisteminin birbirine bütünleşik çalışması gerekmektedir. $\mathrm{Bu}$ amaçla önerilen hat, Niğde kent merkezinde bulunan mevcut istasyonla başlayıp, Kayseri kent merkezindeki istasyonda sonlanmaktadır. Ayrıca, hattın Kayseri Havalimanına eklenen bir istasyon sayesinde havayolu bütünleşmesi sağlanmıştır. Şekil 3'de NiğdeKayseri arasındaki belirlenen güzergah gösterilmiştir.

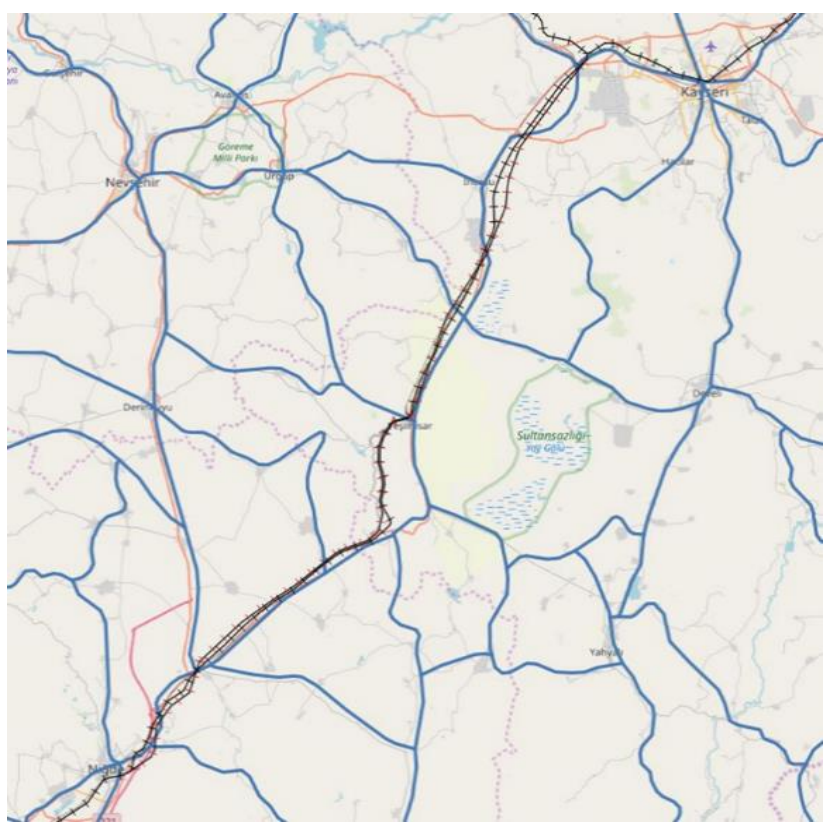

Şekil 3.Belirlenen hızlı tren güzergahının mevcut karayolu ile uyumu

\subsubsection{Nüfus yoğunluğu faktörü}

Raylı sistemler, kalabalık bölgelerde mümkün olan yüksek yolculuklar gerektirir. Bu nedenle, nüfus yoğunluğu da seyahat talebiyle bağlantılı olarak önemli bir değişkendir. Özellikle seyahat üretim noktaları açısından belirleyicidir. Çalışmada mevcut hat üzerinde çalışıldığından bu değişken hattın güzergahının belirlenmesi üzerinde belirleyici olmamıştır.

\subsubsection{Sit alanlarına uzaklık faktörü}

Raylı sistemin güzergah tasarım sürecinde konu genelde yolculuk sayıları, topografyanın elverişliliği, teknolojik ve ekonomik kısıtlar vs. kriterler üzerinden ele alınmaktadır. Fakat bütün bu süreçler ve uygulama neticesinde çevreye mümkün olduğunca zarar verilmemesi gerekmektedir. Bu nedenle kentsel, tarihi, arkeolojik ve doğal sit alanları dikkate alınarak güzergahlar belirlenmelidir. Hattın kuzey batısında Kapadokya tarihi bölgesi, güney doğusunda Sultan Sazlığı sit alanları (Şekil 4) bulunmaktadır. Bu sit alanları dikkate alınarak güzergah seçimi yapılmıştır.

\subsubsection{Mülkiyet faktörü}

Raylı sistem hatlarına ait güzergah ve fizibilite çalışmaları yapılırken kamulaştırma süreçleri de dikkate alınır. Bir güzergahta kamulaştırma hem maliyetlerin artması hem de hukuken sıkıntılı süreçlerin yaşanması anlamına gelir. $\mathrm{Bu}$ nedenle, mümkünse kamulaştırma gerektiren mülklerin değil yerel yönetimlere veya hazineye ait parsellerden geçiş sağlanmalıdır. Seçilen güzergah mevcut Niğde-Kayseri demir yoluna paralel seçilmiştir.

\subsubsection{Ticaret ve sanayi alanlarına yakınlık faktörü}

İstanbul için yapılan hane halkı araştırmalarına göre, evden işe ve işten eve seyahatler tüm seyahatlerin \% 32'sini oluşturmaktadır [16]. Önerilecek raylı sistem güzergahlarının merkezi iş alanları ve sanayi bölgelerinden geçmesi tercih edilmektedir. Böylelikle bu bölgelere kendi özel araçlarıyla veya otobüs ile ulaşan yolcuların toplu taşıma sistemine kayması mümkün olabilecektir. Seçilen güzergah yakınında Kayseri de bulunan İncesu Organize Sanayi ve Merkez Organize Sanayi Bölgeleri bulunmaktadır (Şekil 4).

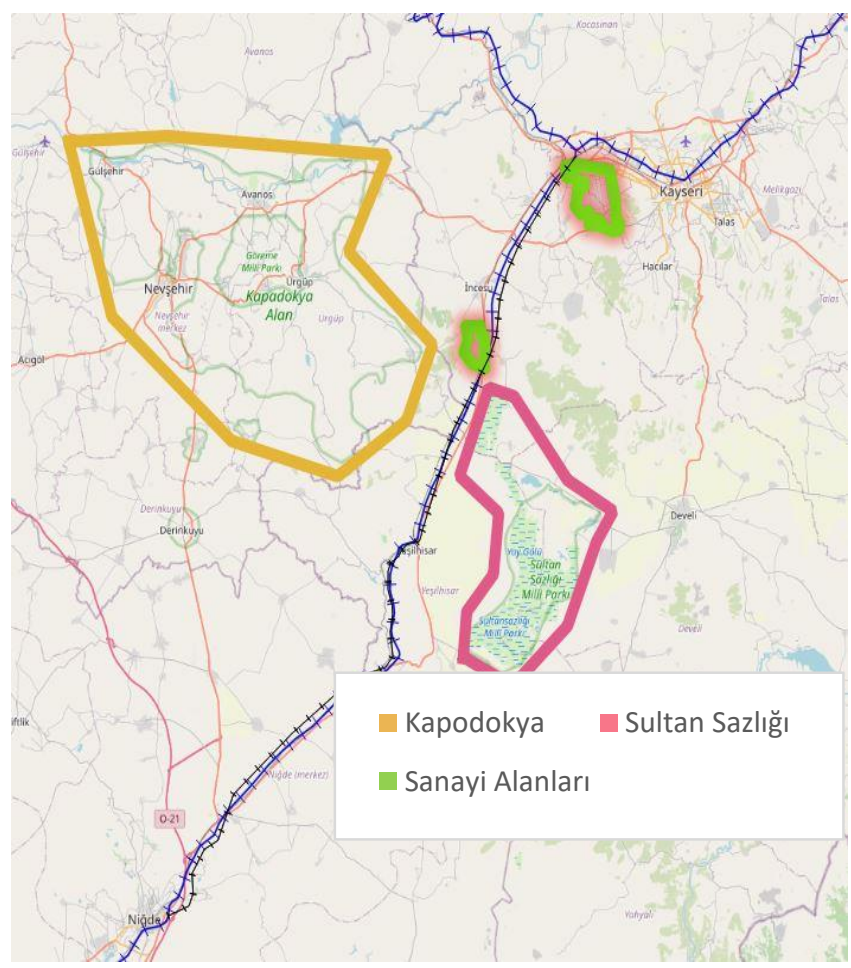

Şekil 4. Niğde-Kayseri bölgesi sanayi alanları ve sit alanları

\subsubsection{Kamu ve eğitim kurumlarına yakınlık faktörü}

Kalabalık kentlerde ev bazlı kamu ve eğitim kurumları yolculukları toplam yolculukların \%21.4'ni oluşturmaktadır [16]. Hattın her iki ucu kent merkezinde yer aldığından kamu ve eğitim kurumlarına toplu taşıma ve erișim olanakları sağlanmıştır.

\subsubsection{Toplu konut alanlarına yakınlık faktörü}

Kayseri'de son yıllarda benimsenen çok merkezlilik politikaları neticesinde şehir merkezinde toplu konutlar artmış ve tarım arazileri kullanılmaya başlanmıştır. Niğde ve Kayseri arasındaki yolculuk süresinin azalması ve erişimin kolaylaşması Niğde için göç yaratmadan istihdam sağlamaya katkıda bulunabileceği düşünülmektedir. 


\subsubsection{Topografya faktörü}

Arazideki eğim ve kot farklılıkları raylı sistem tasarım sürecinde çok önemlidir. Yüksek hızlı trenlerin yüksek hızlarda çalışması nedeniyle boyuna eğimin (maksimum \%3.5) belirli sınırlar içinde kalması gerekir. YeşilhisarAraplı kesiminde topografya engebeli (Şekil 5) olduğundan bu bölge için yedi kilometre uzunluğunda bir tünel planlanmıştır.

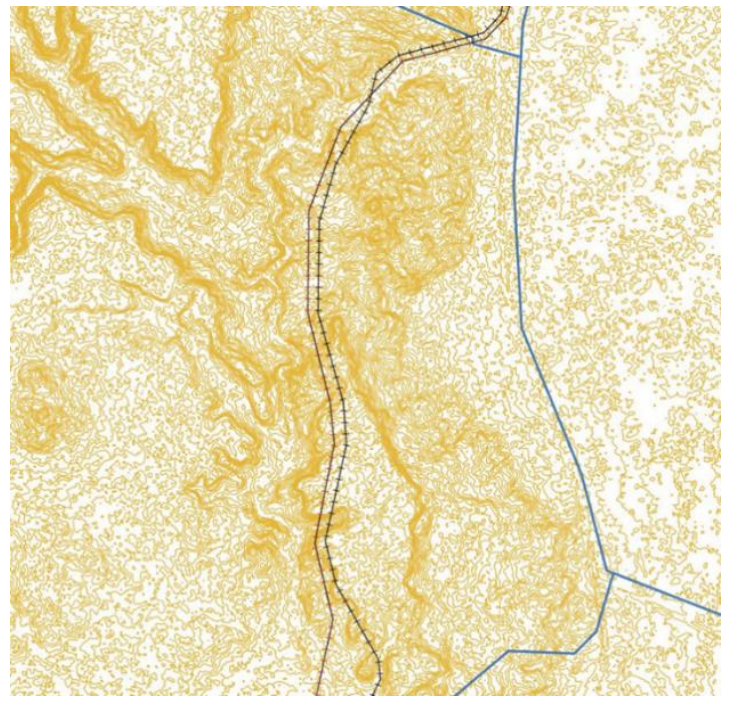

Şekil 5. Niğde-Kayseri hızlı tren hattının QGIS programı yardımıyla çıkarılmış topografik haritası

\subsubsection{Litolojik yapıya uygunluk faktörü}

Planlanan güzergahın litolojisi maliyet hesaplamaları için önemli bir faktörüdür. Sert yapıdaki zeminlerden geçen güzergahlarda yarma maliyeleri ve adam-saat süreleri artmaktadır. Aynı şekilde gevşek bir zeminden güzergahın geçmesi halinde ise güzergahta çökmeler meydana gelecektir. Hızlı trenlerde eğimin düşük olmasından dolayı çoğu zaman sanat yapıları yapılması zorunlu olmaktadır. Sanat yapılarının ve hattın iyi etüt edilmemiş zeminlerde yapılması sadece hizmetin aksamasına değil, kaza gibi ciddi sonuçlara neden olabilmektedir. Şekil 6'da Niğde-Kayseri arası uydu analizi yüzey kayaçları gösterilmiştir. Şekil 7'de bu kayaçların türünü göstermektedir.

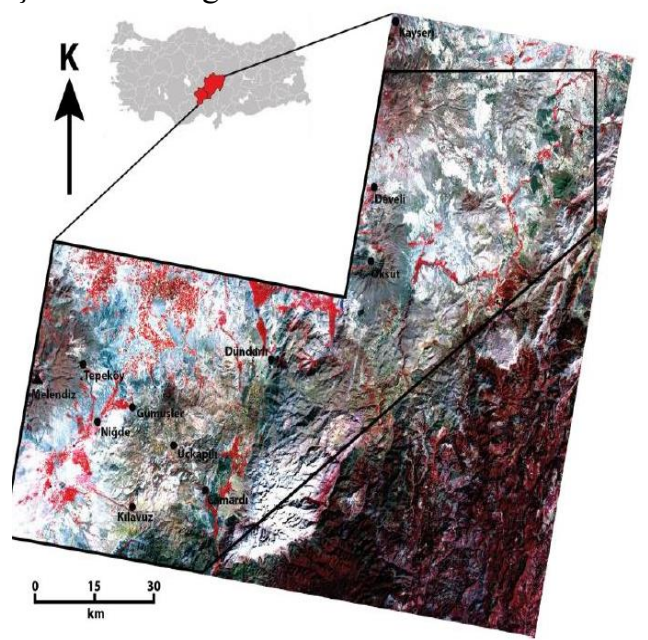

Şekil 6. Niğde-Kayseri bölgesi litolojik analiz [19]

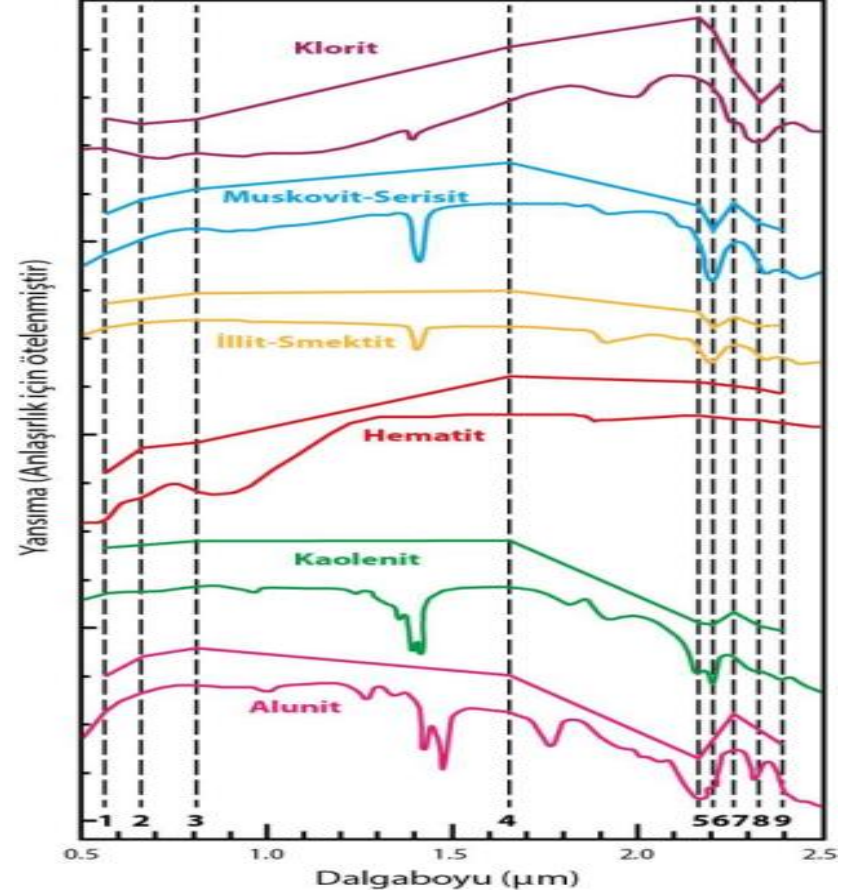

Şekil 7. Niğde-Kayseri bölgesi litolojik analiz [19]

\subsubsection{Fay hatlarına uzaklık faktörü}

Deprem riski göz önüne alınması gereken bir diğer önemli faktördür. Güzergah çalışmaları sırasında fay hatlarının coğrafi konumları ve özellikleri çok iyi bilinmelidir. Fay hattının dikine yapılacak geçişler olası bir kırılmadan çok etkilenmeyecek olmakla beraber, fay hattının üzerinde ya da yakınında fay hattına paralel yapılacak bir geçiş uygun değildir. Bu nedenle fay hatlarının iyi tanınması ve mümkün olduğunca uzaktan geçilmesi gerekmektedir. Çalışılan güzergahta fay hatlarından kaçınılmaya çalış1lmıştır (Şekil 8).

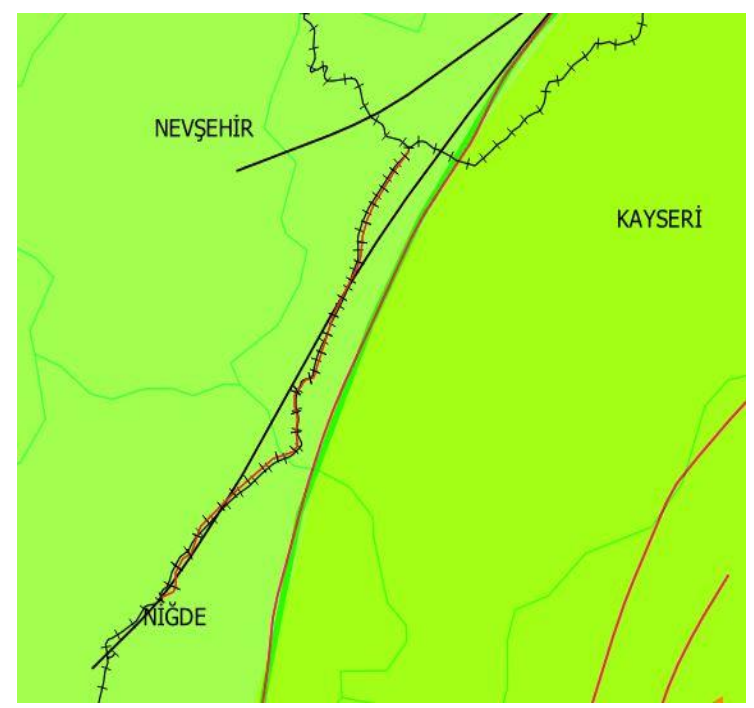

Şekil 8. Niğde-Kayseri bölgesi fay hatları

\subsubsection{Su alanlarına uzaklık faktörü}

Son y1llarda gerçekleştirilen düzenlemelerle dere yataklarında ve havzalardaki yapılaşmalara çok ciddi kısıtlamalar ve yasaklar getirilmiştir. Özellikle içme suyu 
havzaları için geniş ve çok katmanlı koruma kuşakları oluşturularak kentleşmenin bu alanlardaki etkileri kontrol altına alınmaya çalışılmıştır (Şekil 9). Yoğun nüfusa ve yolculuk değerlerine sahip olmayan bu alanlardan raylı sistem geçirilmesi konusunda duyarlılık gösterilmesi gerekmektedir. Seçtiğimiz güzergahta vadi alanlarından ve su toplanma havzalarından kaçınılmıştır (Şekil 10). Sel ve ani su baskını olan bölgelerden uzak tutulmuştur.

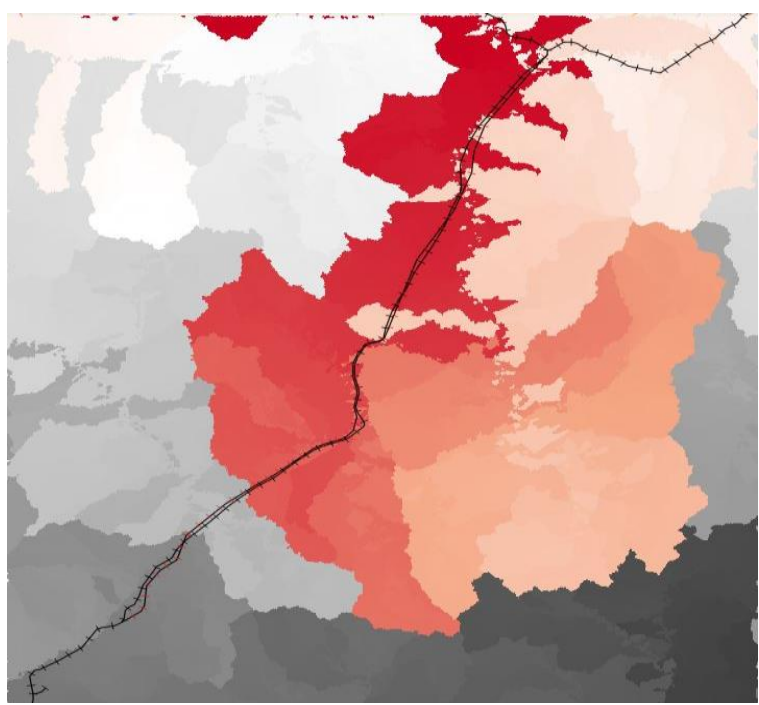

Şekil 9. Niğde-Kayseri bölgesi QGIS programı ile havza analizi

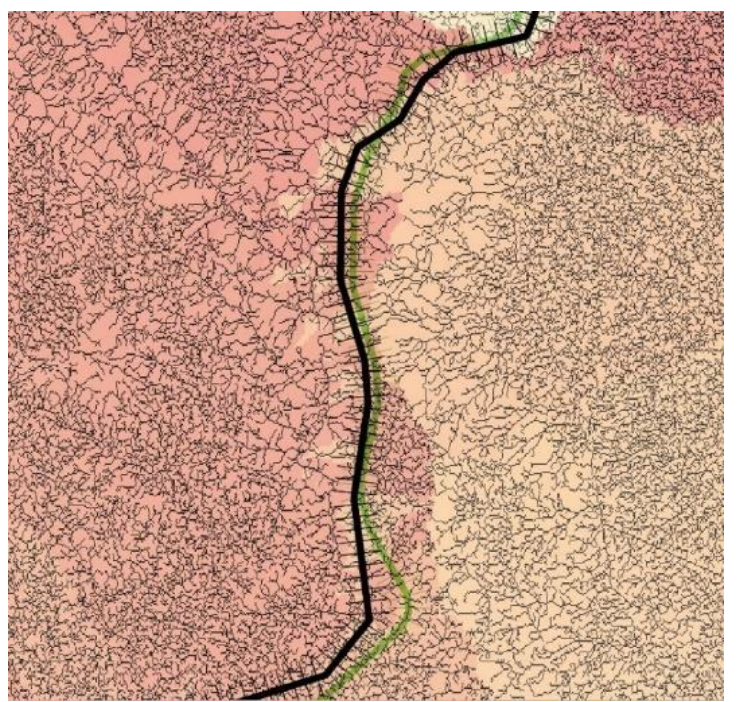

Şekil 10. Niğde-Kayseri bölgesi QGIS programı ile vadi analizi (Yeşil renk mevcut hat-siyah renk hızlı tren hattı)

\subsection{Niğde-Kayseri YHT hattı güzergahının özellikleri}

Yukarıdaki ölçütler dikkate alınarak Niğde-Kayseri hattı için seçilen güzergah Şekil 11'de belirlenmiştir. Bu güzergah mevcut tren hattına paralel olarak belirlenmiş, yükseltinin fazla olduğu yerlerde sanat yapıları ile geçilmeye çalışılmıştır. Hattın kent içindeki bölümü, mülkiyet durumu nedeniyle mevcut hattın üzerinden geçirilmiştir.

Niğde-Kayseri için belirlenen güzergahı başlangıç istasyonu $0+000,00 \mathrm{~m}$, bitiş istasyonu $127+223.88 \mathrm{~m}$ arasında toplam $127.224 \mathrm{~km}$ 'dir. Hat; Kayseri-Yeşilhisar $(0+000,00-73+000.00), \quad$ Yeşilhisar-Araplı $\quad(73+000,00-$ $80+000.00)$ ve Arapl1-Niğde (80+000.00-127+223.88m) olmak üzere üç kesimden oluşmaktadır. Kayseri-Yeşilhisar kesimi balastlı üst yapı (Şekil 12), Yeşilhisar-Araplı kesimi rijit üst yap1 (Şekil 13) ve Arapl1-Niğde kesimi yine balastlı üst yap1 (Şekil 12) biçiminde planlanmıştır. Ayrıca Yeşilhisar-Araplı kesimi yüksek hızlı demiryolu tasarımında maksimum boyuna eğimden dolayı $(\% 2.5)$ bu bölümde yedi kilometre uzunluğunda bir tünel ile Şekil 13'deki gibi geçilmiştir. Tünelin İstanbul-Ankara arasındaki tünel benzer biçimde tasarlanmıştır.

Oluşturulan güzergah üzerinde, Autodesk CIVIL 3D programı yardımı ile dever, eksik dever ve fazla dever hesaplamaları yapılmış ve hat üzerine uygulanmıştır. Şehir merkezlerinde yapılan iyileştirmeler nedeniyle bu kısımlarda hız düşük tutulmuştur. Toplamda 51 yatay kurp oluşturulmuştur. Her bir yatay kurp için dever hesab1 yapılmıştır. Yatay kurplardan biri için Şekil 14'de örnek dever grafiği verilmiştir.

Dever hesabından sonra güzergah boy kesiti oluşturulmuştur. Oluşturulan bu boy kesite yapılan kırmızı çizgi (kot) çalışması sonucunda maksimum hat eğimi \%2.5 olmuştur. $\mathrm{Bu}$ eğim Yeşilhisar-Araplı kesimindeki tünel kısmında kullanılmıştır. Diğer kesimlerde eğim maksimum $\% 1.25$ olmuştur. Şekil 15 'de güzergaha ait boy kesit görülmektedir.

Autodesk CIVIL 3D programı yarma ve dolgu miktarlarını hesaplamıştır. Kayseri-Yeşilhisar, YeşilhisarAraplı ve Araplı Mevki-Niğde arası ayrı ayrı hesaplanmıştır. Kayseri-Yeşilhisar kesiminde 6,838,609.0 $\mathrm{m}^{3}$ yarma, $3,748,145.5 \mathrm{~m}^{3}$ dolgu yapılması gerekmektedir. YeşilhisarAraplı kesiminde tünel işleri olduğundan sadece yarma hesabı yapılmıştır. Tünel yarma miktarı 933,665.3 $\mathrm{m}^{3}$ dür. Arapl1-Niğde kesiminde yarma 46,802.1 $\mathrm{m}^{3}$, dolgu 3,305,139.1 $\mathrm{m}^{3}$ 'dür. Hattın kütle diyagramı Şekil 16'da görülmektedir.

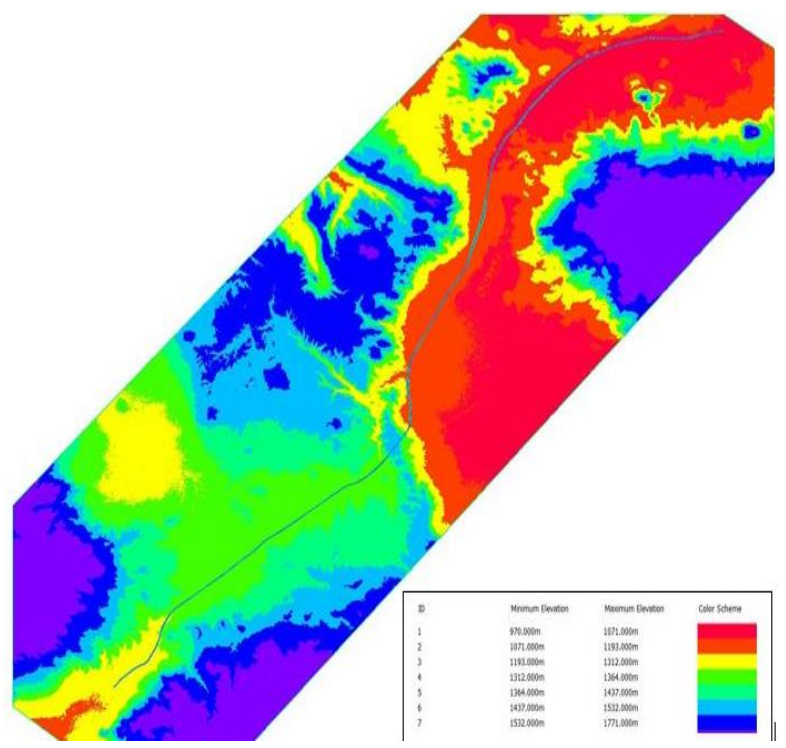

Şekil 11.Niğde-Kayseri arasındaki belirlenen güzergahı 


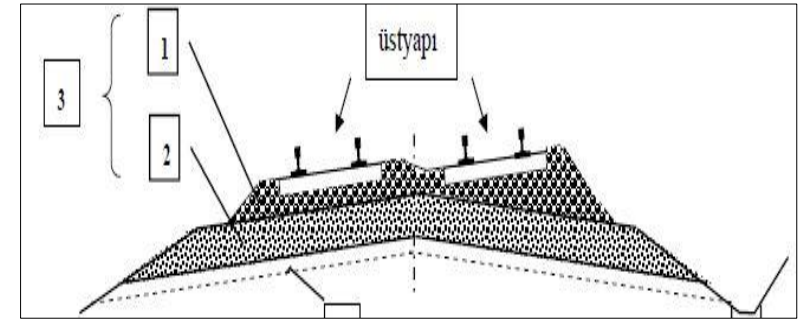

Şekil 12. Balastlı üst yap1

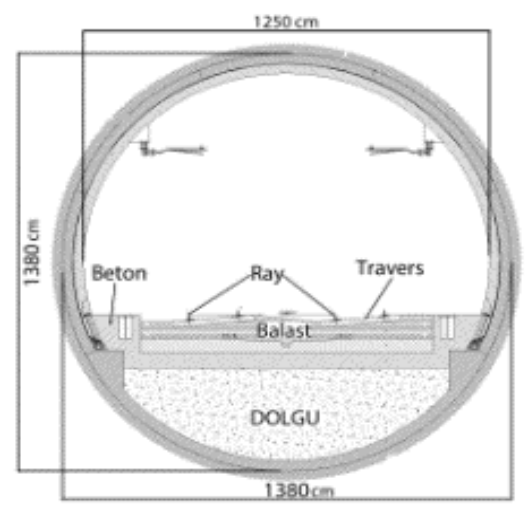

Şekil 13. Yeşilhisar-Araplı arası tünel tip enkesiti

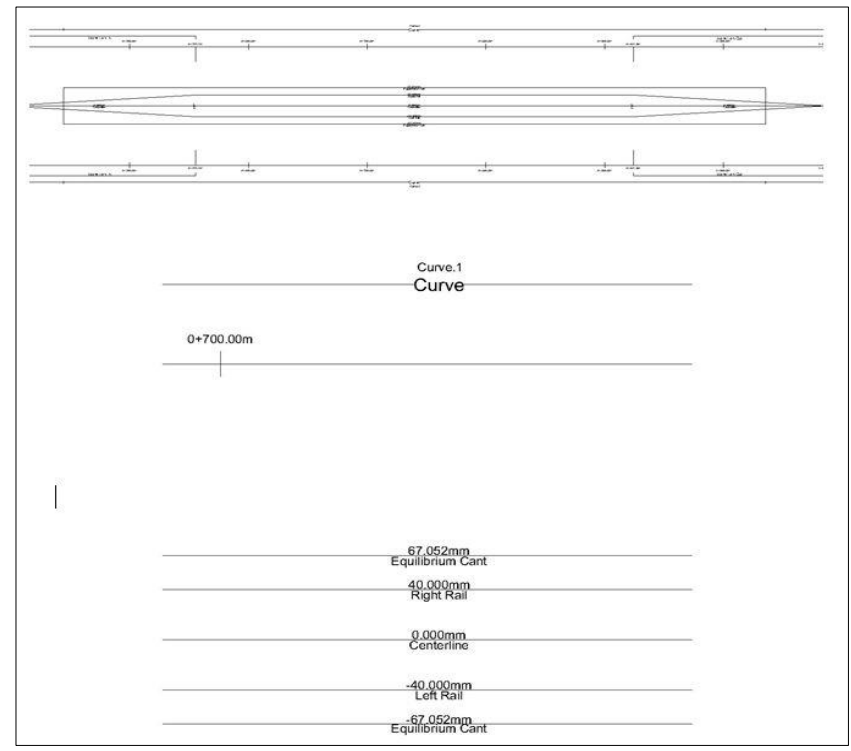

Şekil 14. Yatay kurp dever değeri

Toplam 1757 adet enkesit oluşturulmuştur. Hat genişliği olarak Fransız TGV hat genişliği alınmıştır. Enkesitler hattın uzun olması sebebi ile 100 metrede bir, kurplarda 50 metrede bir oluşturulmuştur. Şekil 17'de örnek en kesit görülmektedir.
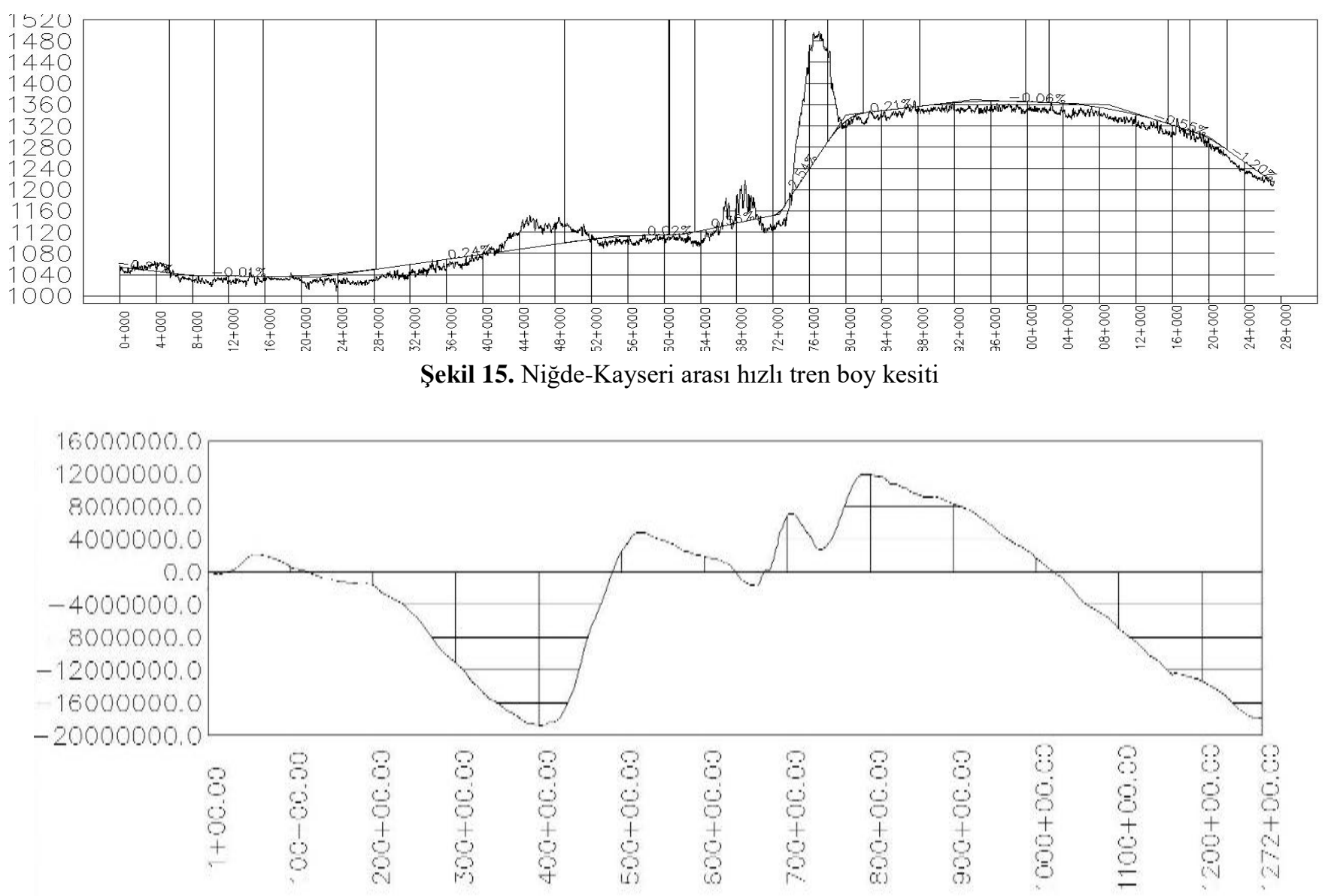

Şekil 16. Niğde-Kayseri arası kütle diyagramı 


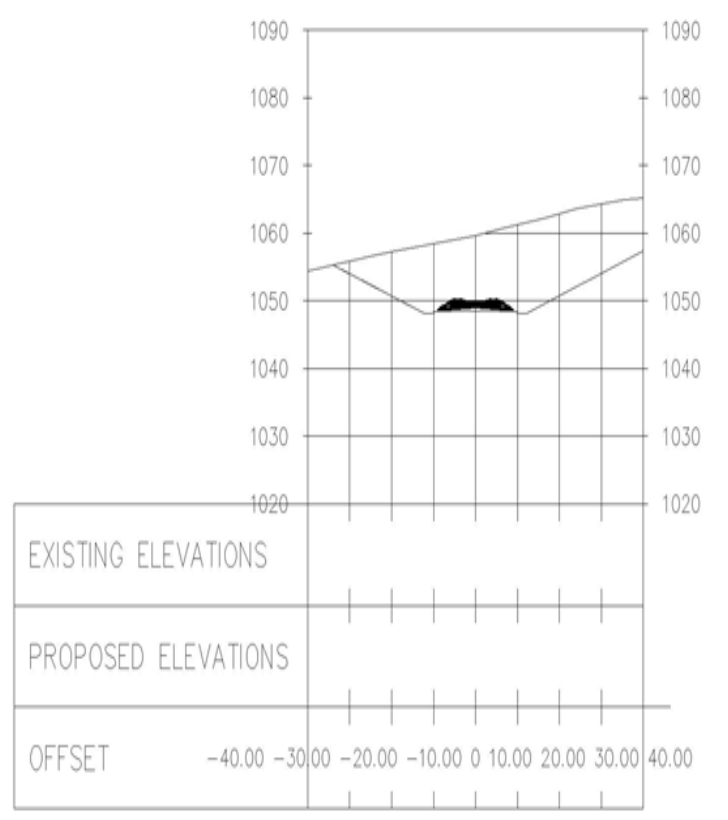

Şekil 17. Uygulanan en kesitten örnek

\subsection{Niğde-Kayseri arası hızlı tren hattı maliyeti}

Türkiye'nin son y1llarda yapılan İstanbul-Ankara, Ankara-Konya ve Ankara-Sivas hızlı tren hatları ile ilgili maliyet çalışmaları mevcuttur. Bu çalışmalar sayesinde Niğde-Kayseri hızlı tren hattına ait önerilen güzergahın yaklaşık maliyet çalışması yapılmıştır.

İstanbul-Ankara Hızlı Tren Hatt1;

Proje, mevcut hattan bağımsız ve tamamen elektrik sinyalli, Ankara ile İstanbul arasında $250 \mathrm{~km} / \mathrm{saat}$ hızda, yeni bir çift hatlı yüksek hızlı demiryolu yapımını içermektedir. Projenin toplam uzunluğu 533 km'dir. Projenin kesimleri Şekil 18'de gösterilmiştir.

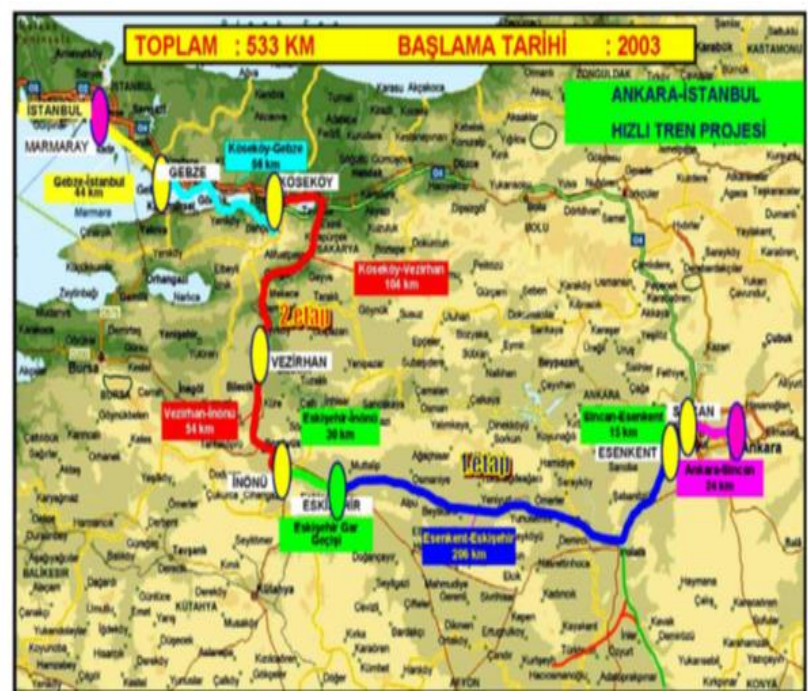

Şekil 18. Ankara ile İstanbul hızlı tren projesi güzergahı ve proje bölümleri [11]

Ankara ile İstanbul hızlı tren hattının toplam maliyeti Tablo 1'deki gibidir.
Tablo 1. Ankara ile İstanbul hızlı tren hattı maliyeti [11]

\begin{tabular}{lcrr}
\hline \multicolumn{1}{c}{$\begin{array}{c}\text { Ankara- İstanbul } \\
\text { Kesimleri }\end{array}$} & $\begin{array}{c}\text { Uzn } \\
(\mathbf{k m})\end{array}$ & $\begin{array}{c}\text { Toplam Bedel } \\
\text { (TL) }\end{array}$ & $\begin{array}{c}\text { Birim Maliyet } \\
\text { (TL/km) }\end{array}$ \\
\hline Ankara-Sincan Kuzey & 24 & $92,000,000$ & $3,833,333.00$ \\
Hattı & 15 & $116,000,000$ & $7,333,333.00$ \\
Sincan-Esenkent & 206 & $1,849,000,000$ & $8,975,728.15$ \\
Esenkent-Eskişehir & 2.2 & $293,000,000$ & $133,181,818.18$ \\
Eskişehir-Gar Geçişi & 30 & $168,000,000$ & $5,600,000.00$ \\
Eskişehir-İnönü & 54 & $2,148,000,000$ & $39,777,777.00$ \\
İnönü-Vezirhan & 71 & $2,790,000,000$ & $39,295,774.64$ \\
Vezirhan-Köseköy & 36 & $168,000,000$ & $4,666,666.00$ \\
Geyve-Arifiye & 56 & $854,000,000$ & $15,250,000.00$ \\
Köseköy-Gebze & 20 & $476,000,000$ & $8,500,000.00$ \\
Gebze-Pendik & & & \\
Toplam & 514.2 & $8,954,000,000$ & $17,413,457.79$ \\
\hline & & &
\end{tabular}

Ankara-Konya Hızlı Tren Hattı;

Toplam uzunluğu $306 \mathrm{~km}$ olan hattın 94 kilometresi Ankara-İstanbul Hızlı Tren Projesi kapsamındaki AnkaraPolatlı kesiminden oluşmaktadır. Projenin toplam hat uzunluğu $212 \mathrm{~km}$ olup, ihaleye 2 ayrı parça halinde çıkılmıştır (Şekil 18). Bölüm $1(0+00-100+00$ km arası) ilk $100 \mathrm{~km}$, Bölüm $2(100+00-212+50 \mathrm{~km}$ arası) $112.5 \mathrm{~km}$ olarak belirlenmiştir. Hattın genel özellikleri Tablo 2'de gösterilmiş̧tir.

Tablo 2. Ankara ile Konya arasındaki hızlı tren hat özellikleri [11]

\begin{tabular}{lll}
\hline Tanımı & Hat Özellikleri & Birimi \\
\hline Toplam Uzunluk & 306 & $\mathrm{~km}$ \\
İnşa edilen uzunluk & 212 & $\mathrm{~km}$ \\
Hat sayısı ve tipi & Çift hat, elektrikli, sinyalli & \\
Hız & 250 & $\mathrm{~km} / \mathrm{saat}$ \\
Dingil Yükü & 23 & ton \\
Ekartman & 1435 & $\mathrm{~mm}$ \\
Min Kurp Yarıçapı & 6500 & $\mathrm{~m}$ \\
Maksimum Eğim & $\%$ o16 & \\
Maksimum Dever & 130 & $\mathrm{~mm}$ \\
Düşey gabari & 6,72 & $\mathrm{~m}$ \\
Ray tipi & UIC-60 & \\
Ray Boyu & 36 & $\mathrm{~m}$ \\
Kaynaklı Uzunluk & Sürekli Kaynak & \\
Ray Kalitesi & $900 \mathrm{~A}$ & \\
& Ön-germeli, ön çekmeli & \\
Traversler & monoblok B70 tipi beton & \\
& {$[8]$.} & \\
Subbalast Miktarı & 670000 & $\mathrm{~m} 3$ \\
Balast Miktarı & 988000 & $\mathrm{~m} 3$ \\
Toplam Ray Miktarı & 56135 & ton \\
Travers Miktarı & 137687 & adet \\
\hline
\end{tabular}

Güzergah üzerindeki toplam hafriyat miktarı yaklaşık $27,000,000 \mathrm{~m}^{3}$, toplam dolgu miktarı yaklaşık 13,000,000 $\mathrm{m}^{3}$ tür. 


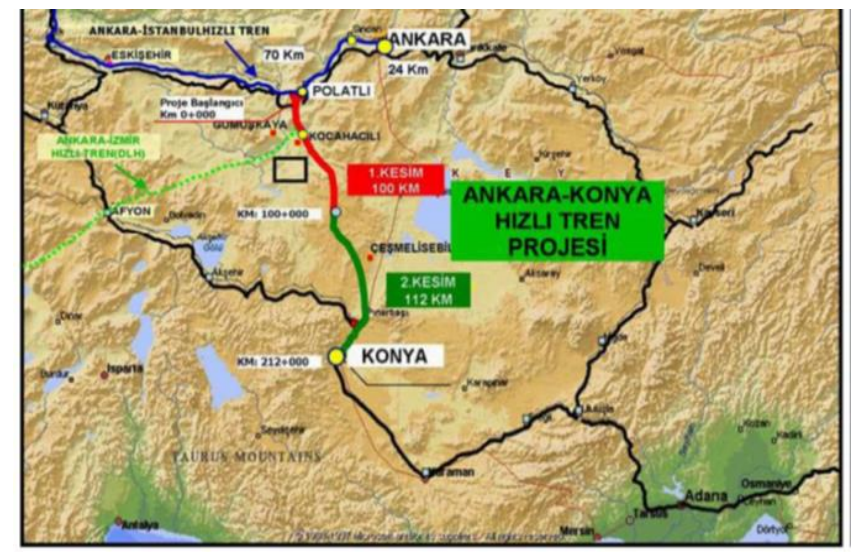

Şekil 19. Ankara-Konya hızlı tren güzergahı [11].

Tablo 3' de görüldüğü üzere Ankara ile Konya hattının kilometre başına maliyeti 3,776,780.26 TL'dir. Dünyadaki örnekleri incelediğimizde (Tablo 4) kilometre yapım maliyetleri arasında farklılıklar görülmektedir.

Tablo 3. Ankara-Konya hızlı tren maliyeti [11]

\begin{tabular}{lc}
\hline Yapım maliyeti & Toplam (TL) \\
\hline 1. Kesim altyapı işleri & $74,890,624.82$ \\
1.Kesim altyapı ikmal işleri & $79,597,097.18$ \\
(keşif artış dâhil) & $83,156,832.00$ \\
2. Kesim altyapı işleri & $35,250,000.00$ \\
2. Kesim altyapı ikmal işleri & $539,630,533.86$ \\
Üstyapı ve elektromekanik işleri & $800,677,415.30$ \\
\hline
\end{tabular}

Niğde-Kayseri hızlı tren hattı için önerilen güzergahın 1. (Kayseri-Yeşilhisar) ve 3. (Araplı Kesimi-Niğde) kesimleri Ankara-Konya hattı ile benzer özellikler sergilemektedir. Ankara-Konya hızlı tren hattının km maliyeti 2011 yılında 3,776,780.00 TL olup 2011 y1lındaki dolar kuru da 1.65 TL'dir. Buna göre dolar cinsinden maliyet 2,288,958.00 $\$ / \mathrm{km}(3,776,780 / 1.65)$ olarak hesaplanmaktadır. Hattın 1. Bölümü 73 km, 3. Bölümü 47.2 km uzunluktadır. Buna göre maliyetler 1. Bölüm için 167,093,934.00 \$, 3. Bölüm için 108,038,818.00 \$ hesaplanmıştır.

Yeşilhisar-Araplı kesimi üzerinde yedi kilometrelik çift hatlı tünel mevcuttur. $\mathrm{Bu}$ kesimde jeolojik özellikler açısından, genelde volkanik kayaçlardan olan, pomzadan oluşmaktadır. Pomza kayacı kolay kazılabilen ve kendini tutabilen bir kayaç türüdür. Tünel kesitinin kazılırken, kazı maliyetlerini aşağıya çekmektedir. HS2 (High Speed Two) verilerine göre çift tüplü tünel maliyeti $\mathrm{km}$ başına $33,000,000.00 €$ olarak belirtilmiştir. Yedi kilometrelik bir tünelin maliyeti buna göre 241,000,000.00 $€$ olarak hesaplanmıştır. Amerikan doları-Euro arasındaki kur oranı 1.188 kabul edilirse tünel maliyeti 284,380,000.00 \$ olmaktadır.
Tablo 4. Yüksek hızlı demiryolu hatları ortalama kilometre yapım maliyetleri [11].

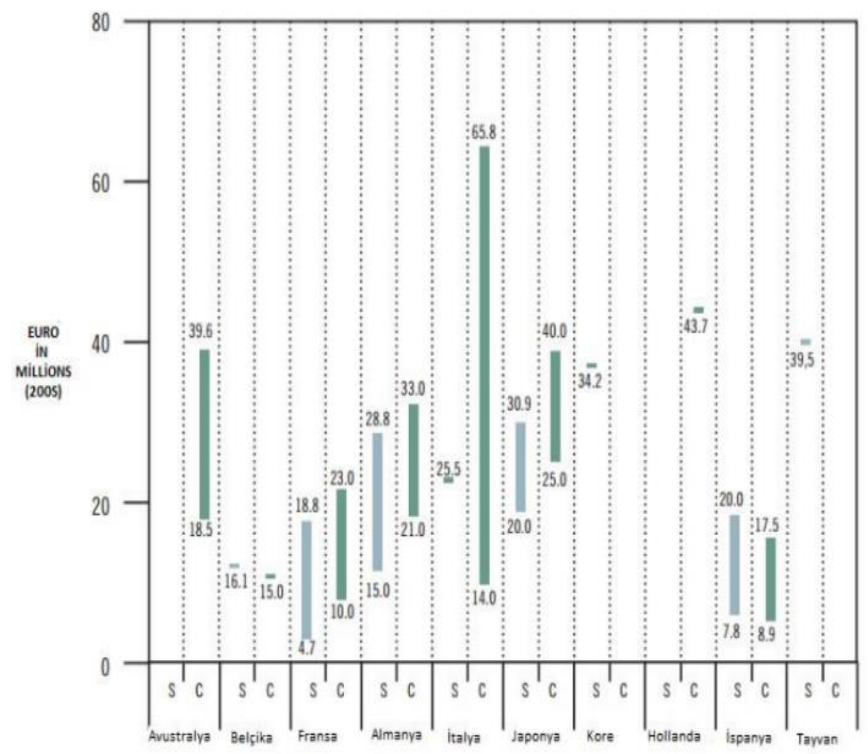

Niğde-Kayseri Arası Hizlı tren hattı kaba maliyeti yaklaşık $392,418,818.00 \quad \$, 2020$ kur oranları ile 2,629,206,080.6 TL $(392,418,818.00 \times 6.7)$ bulunmuştur. Tablo 5'de Niğde-Kayseri arası önerilen hızlı tren hattına ait özellikler listelenmiştir.

\section{Sonuçlar}

Çalışmada, Niğde iline ulaştırma yatırımlarının hangisinin daha uygun ve sürdürülebilir olduğu irdelenmiştir. Bu kapsamda Niğde ilini Kayseri iline daha hızlı bir ulaşım sistemi ile bağlayarak Niğde halkının sosyal, ekonomik ve sağlık alanlarını etkin kullanımı amaçlanmıştır.

Tablo 5. Önerilen Niğde-Kayseri hattına ait özellikler

\begin{tabular}{|c|c|c|}
\hline Hat sayısı ve tipi & \multicolumn{2}{|c|}{ Çift hat, elektrikli, sinyalli } \\
\hline $\mathrm{H} 1 \mathrm{z}$ & 250 & $\mathrm{~km} / \mathrm{sa}$ \\
\hline Dingil yükü & 23 & ton \\
\hline Ekartman & 1435 & $\mathrm{~mm}$ \\
\hline Min. kurp yarıçapı & 6300 & $\mathrm{~m}$ \\
\hline Maksimum eğim & $\% 2.5$ & \\
\hline Maksimum dever & 180 & $\mathrm{~mm}$ \\
\hline Düşey gabari & 6.72 & $\mathrm{~m}$ \\
\hline Ray tipi & UC-60 & \\
\hline Ray boyu & 36 & $\mathrm{~m}$ \\
\hline Kaynak uzunluğu & \multicolumn{2}{|c|}{ Sürekli kaynak } \\
\hline Ray kalitesi & \multicolumn{2}{|c|}{$900 \mathrm{~A}$} \\
\hline Traversler & \multicolumn{2}{|c|}{$\begin{array}{l}\text { Öngermeli, önçekmeli monoblok } \\
\text { B70 tipi beton [8] }\end{array}$} \\
\hline Alt balast miktarı & 395,237 & $\mathrm{~m} 3$ \\
\hline Balast miktarı & 971,265 & $\mathrm{~m} 3$ \\
\hline Toplam ray miktarı & 30,592 & ton \\
\hline Travers miktarı & 336,902 & adet \\
\hline Yarma & 781,076 & $\mathrm{~m} 3$ \\
\hline Dolgu & $705,328,4$ & $\mathrm{~m} 3$ \\
\hline Alt temel & 632,452 & $\mathrm{~m} 3$ \\
\hline Hazırlanmış toprak tabakası & 667,244 & $\mathrm{~m} 3$ \\
\hline
\end{tabular}


Coğrafi bilgi tabanlı ve çok kriterli karar analizi süreçleri, güzergah seçimlerinde etkili bir yöntem olarak karşımıza çıkmaktadır. Bilgisayar tabanlı programların ve bilgisayar donanımlarının gelişmesiyle birlikte büyük ölçekli alanların etkin analizleri yapılabilmektedir. $\mathrm{Bu}$ sayede, yüksek başarımlı bilgisayarlar yardımıyla ulaştırma yatırımlarının ön çalışmasını kısa sürelerde tamamlama şansı sunmaktadır. $\mathrm{Bu}$ alanda çalışma yapan mühendislere kolaylık sağlamaktadır.

Ayrıca çalışmada programların ne kadar etkili olduğu da irdelenmiştir. Bu çalışmada QGIS [20] ve Autodesk CIVIL 3D programları kullanılmıştır. Açık kaynak kodlu olan QGIS programı etkin analizler yapabilmektedir. QGIS programı, topografik analiz, hidrolojik analiz, harita birleştirme, harita çıkartma gibi birçok işlem ve çözümlemeyi yapabilmektir. Program üçüncü taraf uygulamaları için destek vermektedir. Araştırmacı kendi çözümleme kütüphanesini yazma (Python) ve dağıtma olanağına da sahiptir. Autodesk CIVIL 3D programı, QGIS programında oluşturulan harita ve güzergahları, desteklediği geniş dosya biçimi sayesinde kendi çalışma ortamına aktarıp işleyebilmektedir. Autodesk CIVIL 3D oluşturulan bir güzergah üzerine yol yatağ tabakalarını oluşturabilmekte, ayrıca boy kesiti oluşturarak tasarımcıya kolaylıklar sağlamaktadır. Boy kesite kırmızı kotu ekleyerek güzergah alanı üzerinde yarma-dolgu hesaplamalarını, enkesitleri ve güzergah üzerinde kullanılacak rayın, balast tabakasının, alt balast tabakasının, alt temelin ve toprak işlerinin analizlerini kolaylikla yapabilmektedir. Ancak tünel girdilerini tasarımcı kendi oluşturmak zorundadır. Tünel kısmının analizlerinde bazı problemler mevcuttur. Burada tasarımcının tünel kısmındaki verileri kendinin hesaplaması daha faydalı olacaktır.

Araştırılan Niğde-Kayseri hızlı tren hattının tren setleri ile kaba maliyeti 2,629,206,080.6 TL hesaplanmıştır. Yerel bir hava havalimanı için yaklaşı maliyetin 620,849,394.00 TL [21] olduğu düşünüldüğünde dört katı maliyet çıkmaktadır. Ancak işletme maliyetlerinin havalimanlarında \%71,6 [21], hızlı tren işletmeciliğinde \%25,5 [22] düzeyindedir. Ayrıca hızlı tren, uçuş sıklığı, uçuş noktası çeşitliliği, bilet fiyatı ve aktarma sayısı gibi avantajlı bir havalimanı erişimi sağlamasının yanında Niğde kentinin erişilebilirliğine katkıda bulunacaktır. Diğer yandan, yerel havalimanı benzer yoğunluktaki illerdeki havalimanları göz önüne alındığında, yetersiz talep nedeniyle istenen işletme koşullarını sağlamada yetersiz kalması olasılığının yaratabileceği düşük sıklığa sahip uçuşlar ve yüksek bilet fiyatları, kullanıcıların yeniden çevre illerdeki havalimanlarına yönlenmesine yol açabilecektir. $\mathrm{Bu}$ da havalimanını, hızlı tren karşısındaki maliyet avantajını orta ve uzun dönem içinde kaybetme tehlikesini beraberinde getirmektedir.

Niğde-Kayseri hattı üzerindeki Yeşilhisar-Araplı kesiminde topografyanın ani değişmesi sebebi ile yedi kilometre uzunluğunda bir tünel planlanmıştır. $\mathrm{Bu}$ tünel Niğde-Kayseri hızlı tren hattı maliyetinin önemli parçasını oluşturmaktadır.

Maliyet hesaplamaları ülkemizde yapılmış ve halen devam etmekte olan projelerin kilometre maliyetleri göz önüne alınarak yapılmıştır. İstanbul-Ankara hızlı tren hattının 2009 yılındaki maliyeti 8,954,000,000.00 TL'dir. Birim maliyeti 17,413,457.79 TL/km olup 2009 y1lı dolar kuru (1.65) göz önüne alındığında 10,553,610.78 \$/km'dir. Günümüzde fiyatları ile bu maliyet 71,236,872.78 TL'dir. Ankara-Sivas hizlı tren hattının proje bedeli 13,172,263,000.00 TL, birim maliyeti ise 32,284,958.33 $\mathrm{TL} / \mathrm{km}$ 'dir. Niğde-Kayseri hızlı tren hattı toplam maliyeti 2,629,206,080.6 TL olarak kestirilmiştir. Kilometre başına düşen maliyet ise 20,702,410.09 TL/km'dir. Günümüzde dolar kuruna göre karşılığı 3,089,911.95 \$/km'dir. Dünya'daki örneklerle kıyasladığımızda kilometre başına hat maliyetinin Fransa TGV'sinde 3-5 milyon Euro civarında olduğu görülmektedir.

Hattın uzunluğu $127 \mathrm{~km}$ ve proje hızı $200 \mathrm{~km} / \mathrm{s}$ olarak düşünüldüğünde iki uç istasyon arasındaki mesafe tünel geçişleri ve istasyon duraklamaları ile toplam 60 dakika olarak hesaplanmıştır. Havalimanı erişiminde bu süre 45 dakikaya kadar düşmektedir. Niğde kent merkezinden uluslararası bir havalimanına trenle yapılan 45 dakikalık erişim süresi, bu tür bir erişim için uygun olmasının yanında, Kapadokya bölgesindeki turizm hareketliliğine Niğde'nin de uzun vadede eklenmesini sağlayabilir.

Ayrıca hızlı tren yatırımlarının sadece maliyet açısından değerlendirilmesi hatalı olacaktır. Dünya üzerinde karlı işletmeye sahip tren hatları nadirdir. Ülkeler için dikkatli planlanmış ve bütünleştirilmiş raylı sistemler sürdürülebilirlik açısından ulaştırma politikası olarak benimsenmelidir.

\section{Çıkar çatışması}

Yazarlar çıkar çatışması olmadığını beyan etmektedir.

\section{Benzerlik oranı (Turnitin): \%8}

\section{Kaynaklar}

[1] D.H.M.İ, Hava ulaşımı istatistikleri, 2021. https://www.dhmi.gov.tr/Sayfalar/Istatistikler.aspx (Erişim Mar. 28, 2021).

[2] Lufthansa, Rail\&Fly Lufthansa. https://www.lufthansa.com/us/en/rail-and-fly (Erişim Mar. 31, 2021).

[3] Y. Bakış, CBS (Coğrafi Bilgi Sistemi) tabanlı katı atık toplama güzergah optimizasyonu için örnek bir çalışma,Yüksek Lisans Tezi, Bahçeşehir Üniversitesi Fen Bilimleri Enstitüsü, 2012.

[4] C. Kırlangıçoğlu, Coğrafi bilgi sistemleri tabanlı raylı sistem güzergah tasarımı: İstanbul örneği, Doktora Tezi, İstanbul Üniversitesi Sosyal Bilimler Enstitüsü, 2014.

[5] A. Djenaliev, Multicriteria decision makingand GIS for railroad planningin Kyrgyzstan, Master Thesis, KTH, Stockholm (closed 20110301), 2007.

[6] J. E. Kennedy, S. Lyle, R. Smith, ve G. Jeffress, Using cadastral maps to accommodate high-speed rail systems in Texas. The ACSM Annual Conference, Survey Summit, San Diego, CA, July 7-12, 2011.

[7] J. Hasse, A Geographic evaluation of gloucester county commuter rail corridor options a geographic evaluation of gloucester county commuter rail corridor options, Research Report, 2006. 
[8] G. C. Martin R., High speed rail alignment generation and optimization using GIS, Esri International User Conference, San Diego, CA: ESRI, 2012.

[9] W. Bin Zhang, Economic geography and transportation conditions with endogenous time distribution amongst work, travel, and leisure, J. Transp. Geogr., 15(6), 476493, 2007.doi: 10.1016/j.jtrangeo.2007.01.001.

[10] O. Ekim, Yüksek hızlı demiryolları için geometrik özellikler ve altyap1, Yüksek Lisans Tezi, Yıldız Teknik Üniversitesi Fen Bilimleri Enstitüsü, 2007.

[11] A. N. Yüce, Ülkemizde planlanan, yapılmakta olan ve yapılan yüksek hızlı demiryolu hatlarının incelenmesi ve karşılaştırılması,Yüksek Lisans Tezi, İstanbul Teknik Üniversitesi Fen Bilimleri Enstitüsü, 2015.

[12] HKMO, Coğrafi Bilgi Sistemleri. https://www.hkmo.org.tr/resimler/ekler/KOTM_588e6 74d3f0faf9_ek.pdf ,İstanbul, 2005. (Erişim Mart 2021)

[13] X. Wei, Using GIS technology for railway design and management, International Archives of Photogrammetry and Remote Sensing, 978-981.1996

[14] MTA Genel Müdürlüğü. https://www.mta.gov.tr/ v3.0/birimler/uzaktan-algilama(Erişim Mar. 28, 2021).

[15] About ArcGIS | Mapping \& Analytics Software and Services. https://www.esri.com/en-us/arcgis/aboutarcgis/overview (Erişim Mar. 28, 2021).

[16] İBB, İstanbul metropoliten alanı kentsel ulaşım ana planı (İUAP), İstanbul, 2011.

[17] Biletall, Uçak ve Otobüs Bileti Satış Sitesi. https://www.biletall.com/otobusseferler?NeredenId $=990 \&$ NereyeId $=738 \&$ GTarih $=29$. 03.2021\&gidisDonusMu=false \&DTarih=05.04.2021 ( Erişim Mar. 28, 2021).

[18] K.G.M., Trafik hacim haritaları. https://www.kgm.gov.tr/Sayfalar/KGM/SiteTr/Trafik/ TrafikHacimHaritasi.aspx (Erişim Mar. 28, 2021).

[19] K. Tözün ve A. Özyavaş, Niğde ve Kayseri Bölgelerinde yüzeylemiş kayaçların alterasyon özelliklerinin ASTER uydu görüntüleri yardımıyla tespit edilmesi, 6. Uzaktan algılama-CBS sempozyumu (UZAL-CBS 2016), sayfa 557-566, Adana, 5-7 Ekim 2016.

[20] QGIS Development Team, QGIS Geographic Information System. 2021, [Çevrimiçi]. Available at:https://www.qgis.org.

[21] D.H.İ.G.M., Havayolu Sektör Raporları. https://www.dhmi.gov.tr/Sayfalar/HavaYoluSektorRa porlari.aspx (Erişim Mar. 28, 2021).

[22] A. Levinson, D. Gillen, ve D. Kanafani, UC Berkeley The Full Cost Of Intercity Transportation-A Comparison Of High Speed Rail, Air And Highway Transportation In California Publication Date, June. Research Reports, 1996. 